\title{
Analisis Faktor-Faktor Yang Mempengaruhi Minat Berwirausaha Santri Pondok Pesantren
}

\author{
Al Haq Kamal, Nasirothut Thoyyibah \\ Universitas Alma Ata, Jogjakarta \\ *Correspondence adress: kamal.alhaq@uaa.ac.id
}

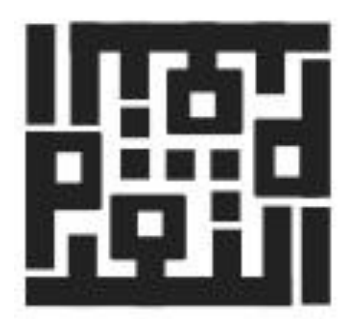 \\ ISSN: 1979-4703 (p) \\ ISSN: 2527-9726 (e)}

Keywords:

Interest, entrepreneurship, students.

\section{A B S T RAC T}

This research is aimed to find out the factors such as the social media, surrounding, intelligence, personality, and individual motivation influenced to entrepreneurship interest of students of Al Munawwir Islamic boarding school, $Q$ complex. This type of research is quantitative descriptive. Data sources in this research are primary data in questionary and secondary data likes the number of student and bistory of Al Munawwir Islamic boarding school, $Q$ complex, Yogyakarta. Population in this research is female students Al Munawwir Islamic boarding school, Q complex, Yogyakarta. The Sample obtained with sampling quota technique that sample total is 63 students. The result indicate that the social media, intelligence, personality, and individual motivation have positive influence on the entrepreneurial interest of students. Only the environment doesn't effect the student entrepreneurial interest in the Al Munawwir Islamic boarding school, Q complex, Yogyakarta.

\section{A B S T R A K}

Penelitian ini bertujuan untuk mengetahui faktor-faktor yang mempengaruhi minat berwirausaha santri Pondok Pesantren Al Munawwir Komplek Q Krapyak Yogyakarta yaitu media sosial, lingkungan, intelegensi, kepribadian, dan motivasi pribadi. Jenis penelitian ini termasuk penelitian deskriptif kuantitatif. Sumber data yang digunakan adalah data primer berupa hasil jawaban dari kuesioner dan data skunder yaitu jumlah santri dan sejarah pondok pesantren. Populasi dalam penelitian ini adalah santri puteri Pondok Pesantren Al Munawwir Komplek Q Krapyak Yogyakarta. Pengambilan sampel dengan teknik sampling kuota, dan diperoleh sampel sebanyak 63 santri. Hasil penelitian ini menunjukkan bahwa media sosial, intelegensi, kepribadian, motivasi pribadi berpengaruh positif terhadap minat berwirausaha santri. Hanya lingkungan yang tidak berpengaruh terhadap minat berwirausaha santri Pondok Pesantren Al Munawwir Komplek Q Krapyak Yogyakarta. 


\section{Pendahuluan}

Santri dikenal sebagai orang yang memiliki sifat mandiri, disebut pula pengambil risiko (risk taker). Santri meninggalkan kenyamanan di rumah dan tinggal di pesantren dengan fasilitas seadanya. Sifat-sifat tersebut adalah sifat dasar seorang entrepreneur. Jika demikian, santri sudah memiliki modal awal untuk menjadi seorang entrepreneur. Tetapi di lapangan bisa dilihat, lulusan Pondok Pesantren dinilai masih minim terjun ke dunia wirausaha. Era millennnial, perkembangan sistem infomasi mempengaruhi minat berwirausaha kaum santri. Hasil penelitian menunjukkan bahwa kepemilikan jaringan dan media sosial berpengaruh dan signifikan terhadap minat berwirausaha mahasiswa (Yuliawan dan Ginting, 2012). Media sosial sebagai peluang bisnis (Mubarok, 2018), dimanfaatkan oleh kaum santri untuk mendapatkan konsumen dengan cara melakukan inovasi dalam bisnis, pemasaran, dan berkomunikasi (Junusi, 2020).

Sistem pendidikan dan lingkungan Pondok Pesantren melatih santri untuk hidup mandiri, hal ini dapat dilihat dalam kehidupan sehari-harinya bahwa mereka harus menyelesaikan urusannya secara mandiri. Hidup di Pesantren, menuntut kaum santri untuk bisa berinteraksi dengan baik dan cerdas mengatur segala kebutuhannya serta harus bisa menyesuaikan diri dengan hal-hal baru. Proses kehidupan di Pesantren melatih intelegensi kaum santri untuk bisa memecahkan masalah-masalah yang dihadapinya. Hasil penelitian menunjukkan bahwa kepribadian mempunyai pengaruh yang signifikan terhadap minat berwirausaha (Ayuningtias dan Ekawati, 2015). Kaum santri harus memiliki kepribadian yang produktif, mempunyai ide kreatif dan inovatif. Selain itu kaum santri juga memiliki motivasi untuk hidup sukses di masa mendatang karena adanya penghasilan yang lebih baik dan tidak mengikat. Hasil penelitian menunjukkan bahwa motivasi mempunyai pengaruh paling tinggi terhadap minat berwirausaha dibanding variabel lain (Ayuningtias dan Ekawati, 2015).

Minat kaum santri untuk menjadi seorang wirausaha dipengaruhi oleh beberapa faktor. Faktor-faktor yang diduga mempengaruhi minat wirausaha adalah media sosial, lingkungan, kepribadian, dan motivasi pribadi. Media sosial yang saat ini menjadi salah satu media promosi produk terbaik menjadi faktor yang diduga mendukung santri mencoba berwirausaha. Sudah sewajarnya kebiasaan seseorang dipengaruhi oleh lingkungan sekitar. Begitu pula minat berwirausaha dapat dipengaruhi oleh lingkungan sekitar. Passion seseorang tergantung pada kepribadian dan motivasi individu. Ketika santri mempunyai keinginan mandiri, mempunyai penghasilan sendiri maka dia dapat memutuskan untuk mencoba berwirausaha.

Ada beberapa penelitian yang sebelumnya pernah dilakukan terkait minat wirausaha santri dan faktor-faktor yang mempengaruhinya, diantaranya yaitu: Indoworo (2016) menyimpulkan bahwa keunggulan layanan sosial media memberikan ruang komunikasi dua arah, yang pada intinya konsumen tidak lagi sebagai objek tetapi subjek pemasaran. Alfaruk (2016) menyimpulkan bahwa secara parsial pemanfaatan sosial media dan motivasi berpengaruh signifikan terhadapa minat berwirausaha mahasiswa ekonomi sedangkan pengetahuan tidak. Secara simultan pemanfaatan sosial media, motivasi, dan pengetahuan berpengaruh signifikan terhadapa minat berwirausaha mahasiswa ekonomi 
di Universitas Muhammadiyah Sidoarjo. Baskara dkk (2018) menyimpulkan bahwa variabel motivasi dan kepribadian berpengaruh positif signifikan terhadap minat berwirausaha mahasiswa, dan variabel lingkungan tidak berpenruh positif signifikan terhadap minat berwirausaha mahasiswa. Ayuningtias, dkk (2015) menyimpulkan bahwa variabel yang paling berpengaruh terhadap minat berwirausaha mahasiswa fakultas ekonomi universitas tarumanegara adalah motivasi. Berikutnya secara berurutan adalah kepribadian, lingkungan keluarga, dan lingkungan kampus. Ulfa, dkk (2015) menyimpulkan bahwa minat berwirausaha kaum santri di pondok Pesantren Ar-Riyadh Palembang berada pada kategori tinggi dengan persentase $96,2 \%$. Secara parsial dan simultan, faktor internal dan faktor eksternal berpengaruh signifikan terhadap minat wirausaha kaum santri di Pondok Pesantren Ar-Riyadh Palembang. Pradipta (2015) menyimpulkan bahwa minat berwirausaha mahasiswa di bidang wisata alam termasuk dalam kategori baik, dengan skor rata-rata 69,89. Faktor yang mempengaruhi yaitu Lingkungan Keluarga, Lingkungan Pendidikan, Lingkungan Sosial, Mata Kuliah, dan Pengalaman Wirausaha. Penelitian ini bertujuan untuk mengetahui faktor-faktor yang mempengaruhi minat berwirausaha santri Pondok Pesantren Al Munawwir Komplek Q Krapyak Yogyakarta yaitu media sosial, lingkungan, intelegensi, kepribadian, dan motivasi pribadi.

\section{Landasan Teori}

\section{Minat}

Minat adalah rasa lebih suka dan rasa ketertarikan pada suatu hal tanpa ada yang menyuruh (Djaali, 2007). Minat dapat diekspresikan melalui suatu pernyataan yang menunjukkan lebih menyukai suatu hal daripada hal lainnnya, dapat pula dimanifestasikan melalui partisipasi dalam suatu aktifitas. Minat adalah perasaan senang atau kecenderungan hati yang mengarahkan individu kepada suatu pilihan tertentu dan berpartisipasi terhadap kegiatan yang menjadi objek kesenangannya tersebut (Suryaman, 2006). Tingkat prestasi seseorang ditentukan oleh perpaduan antara bakat dan minat. Apabila individu menaruh minat terhadap sesuatu hal, ini disebabkan karena obyek itu berguna untuk memenuhi kebutuhannya. Minat tidak dibawa sejak lahir, melainkan diperoleh kemudian (Slameto, 2003). Minat dapat timbul melalui proses, dengan adanya perhatian dan interaksi dengan lingkungan minat tersebut berkembang.

\section{Pengertian Wirausaha}

Kata "entrepreneur" berasal dari bahasa Perancis "entreprendre" yang berarti "melakukan" atau "melaksanakan" (Lubis, 2014). Wirausaha secara etimologi berasal dari kata "wira" berarti teladan atau patut dicontoh, sedangkan "usaha" berarti berkemauan keras, memperoleh manfaat (Tarmudji, 2006). Jadi seorang wirausaha dapat diartikan sebagai "seseorang yang berkemauan keras dalam melakukan tindakan yang bermanfaat dan patut menjadi teladan hidup". Wirausaha secara umum diartikan sebagai orang yang menjalankan usaha atau perusahaan dengan kemungkinan untung atau rugi. Dalam 
Kamus Besar Bahasa Indonesia (KBBI) wirausaha adalah orang yang pandai atau berbakat mengenai produk baru, menentukan cara produksi baru, menyusun operasi untuk mengadakan produk baru, mengatur permodalannya sendiri serta memasarkannya (Adi, 2003). Wirausaha terbagi menjadi empat kelompok, yaitu: (Ciputra, 2009)

a. Business Entrepreneur, dibagi menjadi dua yaitu: owner entrepreneur (pencipta dan pemilik bisnis) dan professional entrepreneur (orang-orang yeng memiliki daya wirausaha namun mempraktekkannya di perusahaan orang lain)

b. Academic Entrepreneur, akademisi yang mengajar atau mengelola lembaga pendidikan dengan pola dan gaya entrepreneur dengan tetap menjaga tujuan mulia pendidikan.

c. Government Entrepreneur, seorang atau sekelompok orang yang memimpin dan mengelola lembaga negara atau instansi pemerintahan dengan jiwa dan kecakapan wirausaha.

d. Social Entrepreneur, para pendiri dan pengelola organisasi-organisasi sosial yang berhasil menghimpun dana masyarakat untuk melaksanakan tugas-tugas sosial.

\section{Urgensitas Wirausaha}

Islam mengajarkan kepada pemeluknya untuk bekerja dan beramal (Siswanto, 2016). Hubungan agama dengan sektor wirausaha cukup jelas, dan telah dicontohkan Rasulullah Saw dan para sahabat. Perintah untuk bekerja dan berwirausaha juga disebutkan dalam surat Al-Jumu'ah (62) ayat 10. Berdasarkan ayat tersebut, umat Islam diperintahkan untuk berusaha dan berwirausaha agar mendapatkan rizki dari Allah sebagai sumber penghasilan. Perintah tersebut bukanlah hal yang biasa karena disandingkan dengan kewajiban untuk melaksanakan shalat Jumat yang merupakan kewajiban bagi setiap muslim. Oleh sebab itu bisa disimpulkan bahwa berwirausaha merupakan kewajiban bagi umat Islam untuk memperoleh rezeki yang halal. Sebuah Hadits riwayat Imam Ahmad, disebutkan: (Ahmad, No. 16628) "..ditanyakan; Wahai Rasulullah, pekerjaan apa yang paling baik? Beliau menjawab; pekerjaan seseorang yang dilakukan dengan tangannya dan tiap-tiap jual beli yang baik.”

\section{Sikap Mental Wirausaha}

Aspek lain yang juga terkait sangat erat yakni masalah mentalitas. Sebagaimana terlihat dalam doa Rasulullah, sikap mental seorang muslim dapat mempengaruhi kualitas pribadi dan kinerjanya. Menurut studi yang dilakukan oleh para peneliti dari Universitas Harvard, keberhasilan orang-orang sukses ternyata lebih banyak ditentukan oleh sikap mentalnya dibandingkan dengan peranan kemampuan teknis yang dimiliki. Perbandingannya adalah 85\% sikap mental dan 15\% kemampuan teknis (Hakim, 1999). Data yang lain menunjukkan bahwa "bangunan wirausaha" terdiri atas tiga unsur dengan komposisi: 58\% mentalitas, 32,5\% manajerial, dan 9,5\% pengetahuan teknis (Priyono dan Soerata, 2005). Aspek mentalitas wirausaha memang banyak disorot, diantaranya dapat diamati dari para wirausaha yang telah terbukti sukses di Indonesia. Sikap mental dari seorang wirausaha adalah memiliki komitmen yang tinggi terhadap usahanya 
sehingga siap untuk menerima risiko dan tetap menjaga integritas dirinya dalam berwirausaha (Husada, 1996).

\section{Minat Berwirausaha}

Minat berwirausaha adalah kecenderungan hati dalam diri seseorang yang tertarik untuk menciptakan suatu usaha yang kemudian mengorganisir, mengatur, menanggung risiko, dan mengembangkan usaha yang diciptakannya tersebut (Subandono, 2007). Minat berwirausaha berasal dari dalam diri seseorang untuk menciptakan sebuah bidang usaha baru. Adapun alasan seseorang berminat untuk berwirausaha, antara lain: (Suryana, 2014)

1. Alasan keuangan, yakni untuk mencari nafkah, menjadi kaya, dan mencari pendapatan tambahan.

2. Alasan sosial, yakni untuk memperoleh gengsi atau status agar dapat dikenal dan dihormati, serta agar dapat bertemu dengan banyak orang.

3. Alasan pelayanan, yakni untuk membuka lapangan pekerjaan dan membantu meningkatkan perekonomian masyarakat.

4. Alasan pemenuhan diri, yakni untuk menjadi mandiri, mencapai sesuatu yang diinginkan, lebih produktif dan untuk menggunakan kemampuan pribadi.

\section{Faktor-Faktor Yang Mempengaruhi Minat Berwirausaha}

Minat berwirausaha tidak dibawa sejak lahir, namun berkembang sesuai dengan faktor-faktor yang mempengaruhinya (Fatrika, 2009). Faktor-faktor yang mempengaruhi minat berwirausaha meliputi karakteristik (jenis kelamin dan usia), lingkungan (lingkungan keluarga, pendidikan, masyarakat), kepribadian (ekstraversi, kesepahaman / agreebleeness, berani mengambil risiko, kebutuhan berprestasi dan independen, evaluasi diri serta overcon_dence / kepercayaan diri yang lebih) dan motif berwirausaha (bekerja dan penyaluran ide kreatif) (Afif dan Budi, 2016). Menurut L. D Crow (2005), menyebutkan faktor yang mempengaruhi minat:

1. The factor inner urge adalah rangsangan yang datang dari lingkungan atau ruang lingkup yang sesuai dengan keinginan atau kebutuhan seseorang.

2. The factor of social motive adalah minat seseorang terhadap objek atau sesuatu hal, dipengaruhi oleh faktor dari dalam juga dipengaruhi oleh motif sosial.

3. Emotional factor adalah faktor perasaan dan emosi, mempunyai pengaruh terhadap objek misal perjalanan sukses yang dipakai individu dalam suatu kegiatan tertentu dapat membangkitkan perasaan senang dan dapat menambah semangat atau kuatnya minat dalam kegiatan tersebut.

Hasil penelitian menunjukkan ada empat hal yang mempengaruhi keputusan berwirausaha, yaitu diri pribadi, lingkungan budaya, kondisi sosial, dan kombinasi dari ketiganya (Peggy, \& Kuehl, 2000). Ada tiga faktor kritis yang berperan dalam minat berwirausaha tersebut, yaitu: (Alma, 2005)

1. Personal (Kepribadian), terkait aspek-aspek kepribadian seseorang. 


\section{At-Taqaddum}

Vol. 12 No. 1 (2020) 75-90

2. Sociological (Hubungan Sosial), terkait bubungan dengan family dan hubungan sosial lainnya. Alma menyatakan masalah hubugan family ini dapat dilihat dari orang tua, pekerjaan, dan status sosial. Dorongan teman juga berpengaruh terhadap semangat berwirausaha, karena dapat berdiskusi dengan bebas dibandingkan dengan orang lain.

3. Environmental (Lingkungan). Faktor yang berasal dari lingkungan diantaranya adalah model peran, peluang, aktifitas, selain itu dipengaruhi juga oleh pesaing, sumber daya, dan kebijakan pemerintah (Suryana, 2014).

Jiwa entrepreneur akan relatif lebih mudah dibentuk melalui pribadi masing-masing dari dalam, dan akan lebih efektif bila dilengkapi oleh kegiatan berinteraksi dengan berbagai faktor dari luar (Suherman, 2010). Berikut beberapa faktor yang mempengaruhi minat berwirausaha antara lain:

\section{Media Sosial}

Menurut Kartajaya (2008), sosial media adalah perpaduan sosiologi dan teknologi yang mengubah monolog (one to many) menjadi dialog (many to many) dan demokrasi informasi yang mengubah orang-orang dari pembaca konten menjadi penerbit konten. Sosial media menjadi sangat populer karena memberikan kesempatan orang-orang untuk terhubung di dunia online dalam bentuk hubungan personal, politik, dan kegiatan bisnis (Indoworo, 2016). Alasan perkembangan internet dapat berkembang dengan cepat adalah: (Turban dan David, 2006) (1) Biaya, (2) Beragam bentuk promosi, (3) Personalisasi, (4) Timeless, (5) Digital branding, (6) Berbasis lokasi pada tempat yang jauh. Perkembangan internet juga membawa pengaruh yang signifkan dalam kegiatan ekonomi dan bisnis. Sebagai situs jejaring, sosial media memiliki peran penting dalam pemasaran. Hal ini disebabkan sosial media dapat memainkan peran komunikasi (Mubarok, 2018). Pada tingkat dasar komunikasi dapat menginformasikan dan membuat konsumen potensial menyadari atas keberadaan produk yang ditawarkan. Komunikasi dapat berusaha membujuk konsumen saat ini dan konsumen potensial agar berkeinginan masuk kedalam hubungan pertukaran (exchange relationship) (Indoworo, 2016).

\section{Lingkungan}

Entrepreneurial process akan terjadi dan diperkuat oleh keberadaan kondisi atau faktor lingkungan. Faktor ini terdiri dari lingkungan fisik, lingkungan ekonomi, lingkungan organisasi, dan kelembagaan serta lingkungan individu. Banyak peneliti yang mengatakan bahwa pekerjaan orang tua yang entrepreneur, 50\% lebih akan menghasilkan pula seorang anak entrepreneur. Selain pengaruh role model lingkungan dari keluarga, terdapat pula lingkungan organisasi yang biasanya memberikan pengaruh terhadap minat berwirausaha. Dalam lingkungan Pondok Pesantren, minat berwirausaha ini dapat dipengaruhi oleh para Asatiz/Asatizah, teman-teman, dan para alumni yang telah sukses dalam berwirausaha sehingga santri terdorong untuk menjadi wirausaha. 


\section{Intelegensi}

Kata intelegensi berasal dari bahasa latin yaitu "inteligensia". Sedangkan kata "inteligensia" sendiri berasal dari kata inter dan lego, inter yang berarti diantara, sedangkan lego berarti memilih (Assagaf, 2010). Intelegensi pada mulanya mempunyai pengertian kemampuan untuk memilih suatu penalaran terhadap fakta atau kebenaran. Intelegensi dapat diartikan sebagai kemampuan menyesuaikan diri dengan lingkungan atau belajar dari pengalaman. Dalam kaitannya dengan minat berwirausaha, seseorang dapat lebih peka terhadap kondisi perekonomian pada saat ini, dimana terdapat kesulitan dalam hal memperoleh pekerjaan sehingga seringkali menuntut individu untuk berpikir lebih baik dengan membuka lapangan kerja sendiri.

\section{Kepribadian}

Kepribadian menurut Gordon W. Allport didefinisikan sebagai organisasi dinamis dari peralatan fisik dan psikis individu yang membentuk karakter unik untuk menyesuaikan diri dengan lingkungannya sehingga pribadi yang baik akan membentuk karakter dan watak yang baik pula. Ada beberapa karakter dan watak yang dimiliki oleh para wirausaha, sebagaimana dikemukakan oleh Geoffrey G. Meredit, berikut:

Karakter dan Watak Wirausaha

\begin{tabular}{|c|c|c|}
\hline $\mathrm{NO}$ & KARAKTER & WATAK \\
\hline 1 & $\begin{array}{l}\text { Self convidence and optimistic } \\
\text { (percaya diri dan optimis) }\end{array}$ & $\begin{array}{l}\text { Memiliki kepercayaan diri yang kuat, } \\
\text { ketidaktergantungan kepada orang lain, } \\
\text { individualistis, optimisme }\end{array}$ \\
\hline 2 & $\begin{array}{l}\text { Task and result orientation } \\
\text { (berorientasi pada tugas dan hasil) }\end{array}$ & $\begin{array}{l}\text { Kebutuhan untuk berprestasi, berorientasi } \\
\text { laba, ketekunan dan ketabahan, tekad kerja } \\
\text { keras, mempunyai dorongan kuat, } \\
\text { eneregetik, dan inisiatif }\end{array}$ \\
\hline 3 & $\begin{array}{lrrr}\text { Berani mengambil risiko dan } \\
\text { menyukai tantangan }\end{array}$ & $\begin{array}{l}\text { Kemampuan untuk mengambil risiko yang } \\
\text { wajar }\end{array}$ \\
\hline 4 & Leadership (kepemimpinan) & $\begin{array}{l}\text { Berjiwa } \\
\text { beradaptasi demimpinan, } \\
\text { terbuka orang lain, dan } \\
\text { terhadap saran dan kritik }\end{array}$ \\
\hline 5 & Originality (orisinalitas) & Inovatif, kreatif, dan fleksibel \\
\hline 6 & $\begin{array}{l}\text { Future oriented (berorientasi masa } \\
\text { depan) }\end{array}$ & $\begin{array}{l}\text { Memiliki visi dan perspektif ke masa } \\
\text { depan }\end{array}$ \\
\hline
\end{tabular}

\section{Motivasi Pribadi}

Supardi dan Anwar (2004), mengatakan motivasi adalah keadaan dalam pribadi seseorang yang mendorong untuk melakukan kegiatan tertentu guna mencapai tujuan. Adapun indikator motivasi yang mempengaruhi minat berwirausaha adalah sebagai berikut:

1. Penghasilan 
Penghasilan adalah sesuatu yang diperoleh seseorang berupa uang atau barang yang digunakan untuk memenuhi kebutuhan hidupnya. Keinginan untuk memperoleh penghasilan itulah yang dapat menimbulkan minat seseorang untuk menjadi wirausaha.

2. Penghargaan (status sosial)

Dengan menjadi wirausaha, seseorangakan memperoleh popularitas, menjaga gengsi, dan menghindari ketergantungannya terhadap orang lain. Keinginan untuk meningkatkan harga diri tersebut dapat menjadi motivasi yang dapat meningkatkan minat seseorang untuk menjadi wirausaha.

3. Rasa senang terhadap kewirausahaan

Rasa senang adalah bagian dari motivasi. Rasa senang terhadap bidang kewirausahaan akan diwujudkan dengan perhatian, kemauan, dan kepuasan dalam bidang wirausaha. Hal ini berarti rasa senang terhadap bidang kewirausahaan akan menimbulkan minat untuk menjadi wirausaha.

\section{Metode Penelitian}

Data yang digunakan dalam penelitian ini adalah data primer dan data sekunder. Data primer diperoleh dari kuesioner (angket) yang disebarkan kepada beberapa santri $\mathrm{Al}$ Muawwir Komplek Q Krapyak Yogyakarta. Data skunder diperoleh peneliti secara tidak langsung melalui media perantara lain terkait jumlah santri, sejarah Pondok Pesantren Al Munawwir Komplek Q Krapyak Yogyakarta, serta hal lain yang berkaitan dengan penelitian ini. Populasi dalam penelitian ini adalah santri Pondok Pesantren Al Munawwir Komplek Q Krapyak Yogyakarta dengan jumlah 412 santri dan sampel sebanyak 63 santri yang dipeoleh dengan teknik quota sampling.

\section{Hasil dan Diskusi}

\section{Hasil Pengujian Instrumen Penelitian}

Pengujian instrumen penelitian terdiri dari validitas dan reliabilitas. Validitas instrumen yang dilakukan pada 33 butir pertanyaan dari 6 variabel menghasilkan bahwa 33 butir pertanyaan valid karena $r$ hitung $>$ nilai $r$ tabel . Begitu pula pada pengujian reliabilitas dengan Alpha Cronbach menunjukkan bahwa pertanyaan keenam variabel reliabel sehingga instrumen penelitian sudah layak digunakan.

\section{Asumsi dalam Regresi Linier}

Asumsi yang harus dipenuhi dalam regresi linier adalah normalitas, linieritas, tidak adanya multikolinieritas, dan tidak ada heteroskedastisitas. Kesemua asumsi tersebut harus terpenuhi sehingga model regresi linier tepat dan signifikan digunakan. Untuk mengetahui apakah data yang digunakan berdistribusi normal atau tidak maka harus diuji kenormalan dulu yaitu dengan uji hipotesis distribusi dan melihat plot. Dengan uji hipotesis dihasilkan bahwa data yang digunakan berdistribusi normal karena p-value $>\alpha$ 
$(0,05)$. Dengan normal p-p plot dapat disimpulkan bahwa data berdistribusi normal bila titik-titik data mengikuti garis lurus. Untuk mengetahui bahwa data yang digunakan berdistribusi normal atau tidak maka dapat dilihat dari output normal p-p plot berikut.

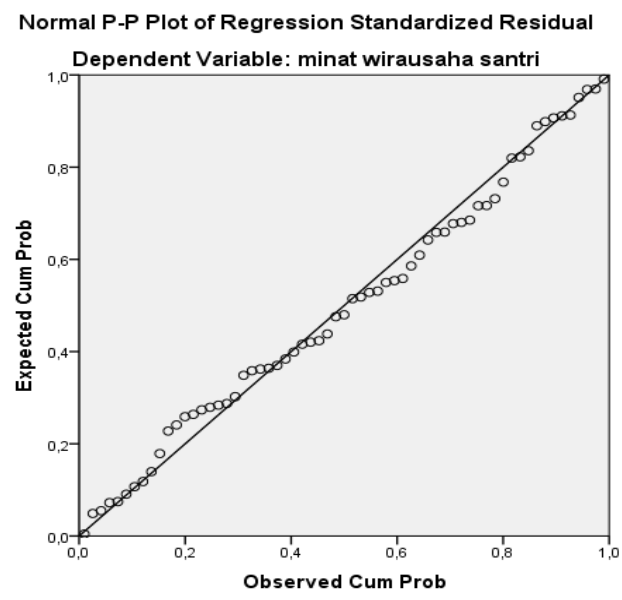

Gambar 1 Normal P-P Plot Minat Berwirausaha

Dari plot di atas terlihat bahwa titik-titik data mengikuti garis lurus sehingga dapat disimpulkan bahwa data minat berwirausaha berdistribusi normal.

\begin{tabular}{lccc}
\hline \multicolumn{1}{c}{ Variabel } & $\begin{array}{c}\text { Sig. } \\
\text { Linearity }\end{array}$ & $\begin{array}{c}\text { Sig. Deviation } \\
\text { From Linearity }\end{array}$ & Keterangan \\
\hline $\begin{array}{l}\text { Minat Berwirausaha Santri }>< \\
\text { Media Sosial }\end{array}$ & 0,000 & 0,683 & Linier \\
\hline $\begin{array}{l}\text { Minat Berwirausaha Santri }>< \\
\text { Lingkungan }\end{array}$ & 0,000 & 0,375 & Linier \\
\hline $\begin{array}{l}\text { Minat Berwirausaha Santri }>< \\
\text { Intelegensi }\end{array}$ & 0,000 & 0,910 & Linier \\
\hline $\begin{array}{l}\text { Minat Berwirausaha Santri }>< \\
\text { Kepribadian }\end{array}$ & 0,000 & 0,057 & Linier \\
\hline $\begin{array}{l}\text { Minat Berwirausaha Santri }>< \\
\text { Motivasi Pribadi }\end{array}$ & 0,000 & 0,374 & Linier \\
\hline
\end{tabular}

Terpenuhi atau tidaknya asumsi linieritas dapat dilihat dari tabel di atas. Hasil tabel di atas menunjukkan bahwa variabel media sosial, lingkungan, intelegensi, kepribadian, dan motivasi pribadi memiliki hubungan secara linier dengan minat berwirausaha santri. Dengan demikian, model regresi linier tepat digunakan untuk kasus ini. Secara statistika, terjadi multikolinieritas bila VIF $<10,00$. Dari tabel di bawah ini terlihat bahwa semua variabel mempunyai $\mathrm{VIF}<10,00$ sehingga tidak terdapat multikolinieritas. 


\section{At-Taqaddum}

Vol. 12 No. 1 (2020) 75-90

\begin{tabular}{llll}
\hline \multirow{2}{*}{ Model } & \multicolumn{2}{c}{ Collinearity Statistics } \\
\cline { 2 - 4 } & \multicolumn{2}{c}{ Tolerance } & VIF \\
\hline \multirow{2}{*}{1} & (Constant) &, 759 & 1,317 \\
\cline { 2 - 4 } & Media Sosial &, 517 & 1,933 \\
\cline { 2 - 4 } & Lingkungan &, 477 & 2,094 \\
\cline { 2 - 4 } & Intelegensi &, 460 & 2,175 \\
\cline { 2 - 4 } & Kepribadian &, 515 & 1,942 \\
\cline { 2 - 4 } & Motivasi Pribadi &
\end{tabular}

Untuk asumsi tidak adanya heteroksidastisitas dapat dilihat dari scatterplot berikut.

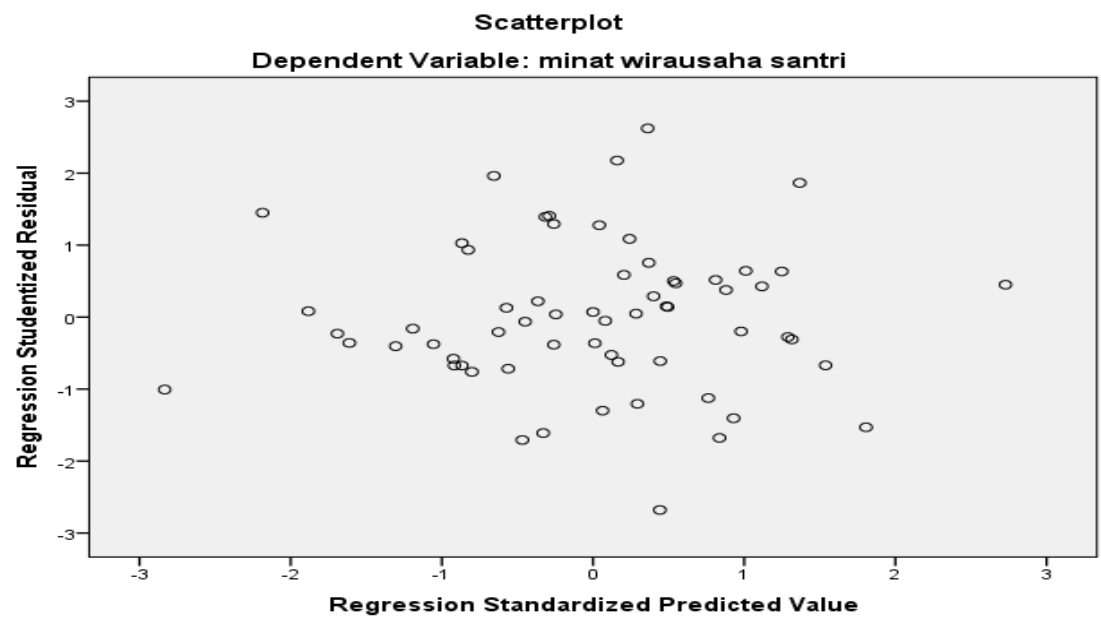

Berdasarkan scatterplot di atas, asumsi tidak ada heteroskedastisitas terpenuhi karena titiktitik datanya menyebar tidak membentuk pola.

\section{Uji Hipotesis}

Uji hipotesis dalam regresi yang digunakan dalam penelitian ini ada tiga, yaitu Uji Koefisien Determinasi $\left(\mathrm{R}^{2}\right)$, Uji F (Simultan), Uji t (Parsial). Koefisien determinasi $\left(\mathrm{R}^{2}\right)$ digunakan untuk mengetahui persentase sumbangan pengaruh serentak variabel-variabel bebas (media sosial, lingkungan, intelegensi, kepribadian, dan motivasi pribadi) terhadap variabel terikat (minat berwirausaha santri). Dari output SPSS diperoleh koefisien determinasi $\left(\mathrm{R}^{2}\right)$ d sebesar 0,688 atau 68,8\% menunjukkan bahwa besar persentase variabel minat berwirausaha santri yang dapat dijelaskan dari variabel bebas yaitu media sosial, lingkungan, intelegensi, kepribadian, dan motivasi pribadi adalah sebesar 68,8\%, sedangkan sisanya $31,2 \%$ dijelaskan oleh variabel-variabel lain di luar model penelitian ini.

Uji F (simultan) pada dasarnya menunjukkan apakah semua variabel independen, yaitu media sosial, lingkungan, intelegensi, kepribadian, dan motivasi pribadi yang dimasukkan dalam model mempunyai pengaruh secara bersama-sama terhadap variabel minat berwirausaha santri.Dari output SPSS diperoleh nilai $\mathrm{F}_{\text {hitung }}$ sebesar 28,384 dan nilai 
p-value sebesar 0,000. Diketahui jumlah sampel $(n)=63$ dan jumlah variabel $(\mathrm{k})=6$, maka diperoleh nilai $\mathrm{df}_{1}=6-1=5, \mathrm{df}_{2}=63-6=57$, sehingga $\mathrm{f}_{\text {tabel }}=2,377$. Hal ini menunjukkan bahwa nilai $\mathrm{F}_{\text {hitung }}>\mathrm{F}_{\text {tabel }}(28,384>2,377)$ dengan $\mathrm{p}$-value $0,000<0,05$, sehingga $H_{0}$ ditolak. Selanjutnya untuk menunjukkan seberapa jauh pengaruh variabel independen secara individual dalam menerangkan variabel dependen dilakukan pengujian parsial dengan uji t.

\begin{tabular}{lcccc}
\hline \multicolumn{1}{c}{ Model } & $\mathbf{t}$ & Sig. & $\begin{array}{c}\text { Hasil Kriteria } \\
\text { Uji }\end{array}$ & Kesimpulan \\
\hline Media Sosial & 2,929 &, 005 & H0 ditolak & Berpengaruh \\
\hline Lingkungan &,- 749 &, 457 & H0 diterima & Tidak berpengaruh \\
\hline Intelegensi & 2,419 &, 019 & H0 ditolak & Berpengaruh \\
\hline Kepribadian & 2,600 &, 012 & H0 ditolak & Berpengaruh \\
\hline Motivasi Pribadi & 4,338 &, 000 & H0 ditolak & Berpengaruh
\end{tabular}

Dari tabel di atas dapat dikatakan bahwa hanya variabel lingkungan yang tidak berpengaruh terhadap minat berwirausaha santri.

\section{Analisis Regresi Linier Berganda}

Analisis regresi linier berganda digunakan untuk mengetahui pengaruh dua atau lebih variabel independen, yaitu media sosial, lingkungan, intelegensi, kepribadian, dan motivasi pribadi terhadap variabel dependen minat berwirausaha santri.

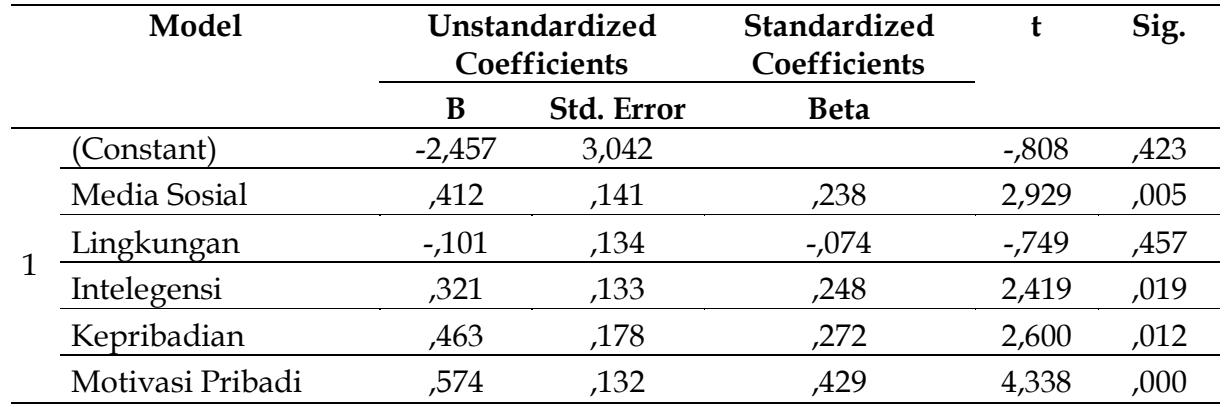

Hasil analisis regresi linier berganda pada tabel di atas, diperoleh persamaan regresi linier berganda yang dapat dirumuskan sebagai berikut: $\mathrm{Y}=(-2,457)+0,412 \mathrm{X}_{1}+(-0,101) \mathrm{X}_{2}+0,321 \mathrm{X}_{3}+0,463 \mathrm{X}_{4}+0,574 \mathrm{X}_{5}+\mathrm{e}$ Hasil dari persamaan regresi linier berganda di atas menunjukkan bahwa:

1) Nilai koefisien regresi untuk variabel media sosial adalah sebesar $+0,412$, artinya setiap kenaikan 1 satuan variabel media sosial akan menyebabkan kenaikan nilai minat berwirausaha santri sebesar 0,412 kali dengan catatan variabel lain dianggap tetap.

2) Nilai koefisien regresi untuk variabel intelegensi adalah sebesar $+0,321$, artinya setiap kenaikan 1 satuan variabel intelegensi akan menyebabkan kenaikan nilai minat 
berwirausaha santri sebesar 0,321 kali dengan catatan variabel lain dianggap tetap.

3) Nilai koefisien regresi untuk variabel kepribadian adalah sebesar $+0,463$, artinya setiap kenaikan 1 satuan variabel kepribadian akan menyebabkan kenaikan nilai minat berwirausaha santri sebesar 0,463 kali dengan catatan variabel lain dianggap tetap.

4) Nilai koefisien regresi untuk variabel motivasi pribadi adalah sebesar $+0,574$, artinya setiap kenaikan 1 satuan variabel motivasi pribadi akan menyebabkan kenaikan nilai minat berwirausaha santri sebesar 0,574 kali dengan catatan variabel lain dianggap tetap.

\section{Pengaruh Media Sosial, Intelegensi, Kepribadian dan Motivasi Pribadi terhadap Minat Berwirausaha Santri Pondok Pesantren Al Munawwir Komplek Q Krapyak Yogyakarta}

Hasil pengujian hipotesis media sosial terhadap minat berwirausaha santri dengan nilai $t_{\text {hitung }} 2,929>t_{\text {tabel }} 2,002$ dan nilai signifikansi $0,005<0,05$, bahwa terdapat pengaruh positif dan signifikan antara media sosial dengan minat berwirausaha santri. Hasil penelitian ini menunjukkan seberapa pengaruh media sosial terhadap minat berwirausaha santri Komplek Q yang dapat digambarkan dengan tingkat kebutuhan santri untuk memperoleh manfaat dari media sosial. Peran media sosial dalam dunia wirausaha sebagai media pemasaran yang sangat menguntungkan dan terjangkau baik dari pihak penjual atau pembeli. Hasil penelitian ini sesuai dengan penelitian yang dilakukan oleh Hawik Ervina Indoworo (2016), dan Muhammad Hasym Alfaruk (2016). Hasil pengujian hipotesis antara intelegensi terhadap minat berwirausaha santri dengan nilai $t_{\text {hitung }} 2,419>$ $\mathrm{t}_{\text {tabel }}$ 2,002 dan nilai signifikansi $0,019<0,05$ menunjukkan bahwa terdapat pengaruh positif dan signifikan. Hasil penelitian menunjukkan kaum santri Komplek Q memiliki kemampuan untuk menyesuaikan diri terhadap hal-hal baru, salah satunya dalam dunia wirausaha. Hasil ini sesuai dengan penelitian Nadhira Ulfa dan Maftukhatusolikhah (2015).

Hasil pengujian hipotesis antara kepribadian terhadap minat berwirausaha santri dengan nilai $\mathrm{t}_{\text {hitung }} 2,600>\mathrm{t}_{\text {tabel }} 2,002$ dan nilai signifikansi $0,012<0,05$, artinya terdapat pengaruh positif dan signifikan antara kepribadian dengan minat berwirausaha santri. Penelitian menunjukkan hasil bahwa santri Komplek Q memiliki rasa percaya diri yang kuat dan mandiri, tekad kerja keras, berjiwa kepemimpinan, berani menghadapi risiko. Kepribadian tersebut sangat sesuai dengan jiwa kewirausahaan yang harus dimiliki oleh seorang wirausahawan. Hasil ini sesuai dengan penelitian yang dilakukan oleh Hazirah Amalia Ayuningtiyas dan Sanny Ekawati (2015).

Hasil pengujian hipotesis membuktikan terdapat pengaruh positif dan signifikan antara motivasi pribadi terhadap minat berwirausaha santri dengan nilai $t_{\text {hitung }} 4,338>\mathrm{t}_{\text {tabel }}$ 2,002 dan nilai signifikansi $0,000<0,05$. Hasil penelitian menunjukkan bahwa santri Komplek Q memiliki motivasi yang tinggi untuk berwirausaha. Motivasi memperoleh hasil nilai yang paling tinggi, hal ini menggambarkan bahwa santri Pondok Pesantren Al Munawwir Komplek Q memiliki minat yang sangat tinggi untuk menjadi seorang 
wirausahawan. Hasil ini sesuai dengan penelitian yang dilakukan oleh Muhammad Hasym Alfaruk (2016).

\section{Kesimpulan}

Berdasarkan hasil penelitian ini, diperoleh kesimpulan bahwa Media sosial, Intelegensi, Kepribadian, dan Motivasi pribadi berpengaruh terhadap minat berwirausaha santri Pondok Pesantren Al Munawwir Komplek Q Krapyak Yogyakarta. Untuk faktor lingkungan tidak mempengaruhi santri berwirausaha.

\section{Daftar Pustaka}

Adi, Gunawan, 2003, Kamus Praktis Bahasa Indonesia, Surabaya: Kartika.

Afif N.R. \& Budi H, Analisis Faktor-Faktor Yang Mempengarubi Minat Berwirausaha Pada Mahasisiwa Program Studi Manajemen Fakultas Ekonomi Universitas Kadiri, Jurnal Ekonomi Universitas Kadiri, EkoNika Vol. 1, No. 2 September 2016: 153-169

Ahmad, Musnad Ahmad, Juz 3, HR. Ahmad, Nomor 16628.

Alma, Buchari, 2005, Kewirausahaan Untuk, Mahasiswa dan Umum, Bandung: Alfabeta.

Amstrong, \& Philip Khotler, 2010, Principle Of Marketing, 7th ed, New Jersey: Prentice, hal. Inc.

Anwar, Muhammad,2014,Pengantar Kewirausahaan: Teori dan Aplikasi, Jakarta: Prenadamedia Group.

Arikunto, Suharsimi, 2009, Manajemen Penelitian, Cet. Ke-10, Jakarta: Rineka Cipta.

Assagaf, Lulu, Pengertian Intelegensi,10 Desember, 2010.

As’ad, Moh., 2008, Psikologi Industri. Edisi Revisi, Yogyakarta: Liberty.

Ayuningtias, Hazirah Amaliah, dan Sanny Ekawati, 2015, Faktor-Faktor Yang Mempengarubi Minat Berwirausaha Pada Mahasiswa Fakultas Ekonomi Universitas Tarumanegara, Jurnal Ekonomi, Vol. XX, No. 01.

Azwar, Saifudin, 2010, Penyusunan Skala Psikologi, Yogyakarta: Pustaka Pelajar.

Basrowi, 2014, Kewirauahaan Untuk Perguruan Tinggi, Bogor: Penerbit Ghalia Indonesia.

Ciputra, 2009, Ciputra Quantum Leap, Jakarta: PT. Gramedia.

Crow, L.D, 2005, Psikologi Pendidikan, Yogyakarta: Penerbit Nur Cahya.

Dalyono, M., 2007, Psikologi Pendidikan, Jakarta: Rineka Cipta.

Djaali, 2007, Psikologi Pendidikan, Jakarta: Bumi Aksara. 


\section{At-Taqaddum}

Vol. 12 No. 1 (2020) 75-90

D.M., Boyd, dan Ellison Nicole, Social Networking Site: Definition, History, and Scholarship, Journal Of Computer - Mediated Communication, Vol. 13, No. 1

Fatrika et.al., 2009, Faktor-Faktor Yang Mempengarubi Minat Wirausaha Mahasiswa Dengan Teknik SEM, Jurnal Matematika, UNAID, Vol. 1 No. 2, Padang: Jurusan Matematika FMIPA, Universitas Andalas.

Fuadi, Hubungan Minat Berwirausaha Dengan Prestasi Praktik Kerja Industry Siswa Kelas XII Teknik Otomotif SMK Negri 1 Adiwerna Kabupaten Tegal, Jurnal PTM 9 (1) Desember

Ghozali, Imam, 2013, Aplikasi Analisis Multivariate Dengan Program (Edisi Ketujub), Semarang: Badan Penerbit Universitas Diponegoro.

- 2006, Metode Penelitian Kuantitatif dan Kualitatif, Yogyakarta: Graha Ilmu.

Hadi, Sutrisno, 2000, Seri Program Statistik-Versi 2000, Yogyakarta: Universitas Gajah Mada.

Hakim, Rusman, 1999, Kiat Sukses Berwirausaha, Jakarta: Elex Media Komputindo.

Has, Agus Baskara Zakir, Pengarub Motivasi, Kepribadian Dan Lingkungan Terbadap Minat Berwirausaha Mahasiswa Fakultas Keguruan Dan Ilmu Pendidikan Universitas Riau, PeKA: Jurnal Pendidikan Ekonomi Akuntansi FKIP UIR Vol. 6 No. 1 Tahun 2018 P - ISSN: 2337-652x | E-ISSN:2598-3253

Hastuti, A. Yahya, 2002, 9 Kunci Bisnis Rasulullah SAW \& Khadijah RA, Jakarta: Penerbit Kalil.

Hisric, R.D., \& Petters Michael P, Entrepreneurship, Fourth Edition, Irwin, USA

Husada, Safarudin, 1996, 36 Profil Wirausaha Sukses Indonesia, Jakarta: Elex Media Komputindo.

Idri, 2016, Hadis Ekonomi: Ekonomi Dalam Perspektif Hadis Nabi, Cet. Ke-2, Jakarta: Prenada Media Group.

Indoworo, Hawik Ervina, Menumbubkan Jiwa Wirausaha Melalui Peran Sosial Media, Jurnal Informatika UPGRIS Volume 2 Nomor 1 Juni 2016.

Jalil, Abdul, M.EI.,2013, Spiritual Enterpreneurship : Transformasi Spiritualitas Kewirausabaan, Cet. Ke-1, Yogyakarta: LKIS Yogyakarta.

Junusi, R. El. (2020). Digital Marketing During the Pandemic Period ; A Study of Islamic Perspective. Journal of Digital Marketing and Halal Industry, 2(1), 15-28. https://doi.org/http://dx.doi.org/10.21580/jdmhi.2020.2.1.5717

Kertajaya, Hermawan, 2008, New Wave Marketing, Jakarta: PT. Gramedia Pustaka Hatama.

Lambing, Peggy, \& Kuehl C.R., 2000, Entrepreneurship, (2nd ed), New Jersey: Prentice_Hal, Inc 
Lubis, S.B. Hari, 2014, Kewirausahaan, Cet. Ke-3, Banten: Universitas Terbuka.

Junusi, R. El. (2020). Digital Marketing During the Pandemic Period ; A Study of Islamic Perspective. Journal of Digital Marketing and Halal Industry, 2(1), 15-28. https://doi.org/http://dx.doi.org/10.21580/jdmhi.2020.2.1.5717

Mubarok, F. K. (2018). Peran sosialisasi dan edukasi dalam menumbuhkan minat investasi di pasar modal syariah. Inovasi, 14(2), 113. https://doi.org/10.29264/jinv.v14i2.4119

Muhamad, 2008, Metodologi Penelitian Ekonomi Islam: Pendekatan Kuantitatif, Ed. I, Jakarta: Rajawali Pres.

Nelson, G.G. Meredith, R.E., dan P.A. Neck, The Practice Of Entrepreneurship (Kewirausahaan: Teori Dan Praktek), Diterjemahkan Andre Asparsayogi, Jakarta: Pustaka Binawan Pressindo.

Priyanto, Sony Heru, Mengembangkan Pendidikan Kenirasuahaan Di Masyarakat, Andragogia - Jurnal PNFI, Vol. 1. No. 1, November 2009.

Priyono, Susilo, dan M. Soerata P.S., 2005, Kiat Sukses Wirausaha, Jakarta: Palem Pustaka.

Purwanto, 2010, Instrument Penelitian Sosial dan Pendidikan (Pengembangan dan Pemanfaatan), Cet. Ke-2, Yogyakarta: Pustaka Pelajar.

Siswadi, Yudi, "Analisis Faktor Internal, Faktor Eksternal dan Pembelajaran Kenirausahaan Yang Mempengarubi Minat Mahasiswa Dalam Berwirausaha", Jurnal Manajemen dan Bisnis, Vol. 13,01 April 2013.

Siswanto, Tito, Optimalisasi Sosial Media Sebagai Media Pemasaran Usaha Kecil Menengah, Jurnal Liquidity Vol. 2 No. 1, Januari-Juni 2013

Siswanto, Agus, 2016, The Power Of Islamic Entrepreneurship: Energi Kewirausabaan Islami, Jakarta: Amzah.

Slameto, 2003, Belajar dan Faktor-Faktor Yang Mempengarubinya, Jakarta: Rineka Cipta.

Subandono, Aris, 2007, Pengarub Life Skill Diklat Kimia Produktif dan Prestasi Belajar Diklat Kewirausahaan Terhadap Minat Berwirausaha Pada Siswa SMK Kimia Industry Theresiana Semarang, Semarang: FMIPA-UNES,

Suherman, Eman, 2010, Business Entrepreneur, Cet. Ke-2, Bandung: Alfabeta.

Supardi, dan Anwar, 2004, Dasar-Dasar Perilaku Organisasi, Yogyakarta: UII Press.

Suryaman, Maman, 2006, Minat Berwirausaha Pada Mahasiswa Pendidikan Teknik Elektro Fakultas Teknik Universitas Negeri Semarang, Semarang: Universitas Negeri Semarang.

Suryana, 2014, Kewirausahaan: Kiat dan Proses Menuju Sukses, Jakarta: Salemba Empat.

Tarmudji, Tarsis, 2006, Prinsip-Prinsip Kewirausahaan, Yogyakarta: Liberty. 
Tilaar, H.A. R., 2012, Pengembangan Kreatifitas dan Entrepreneurship Dalam Pendidikan Nasional, Kompas.

Ulfah, Nadhirah, dan Maftukhatusolikhah, 2015,Pengarub Faktor Internal dan Faktor Eksternal Terbadap Minat Wirausaha Kaum Santri Di Pondok Pesantren Ar-Riyadh Palembang, Skripsi UIN Raden Fatah Palembang

Yuliawan, Eko, dan Mbayak Ginting, Analisis Faktor-Faktor Yang Mempengarubi Minat Berwirausaba Mahasiswa (Studi Kasus Pada STMIK Mikroskil Medan), Jurnal Wira Ekonomi Mikro Skil, Vol. 2, No. 02, Oktober, 2012. 